
\title{
G NORK \\ Persistent Privilege? Institutional Education Gaps during Vietnam's Economic Boom
}

\author{
Diep Phan \\ Ian Coxhead \\ Working Paper \\ 2020-023 \\ $04 / 2020$
}

HUMAN CAPITAL AND

ECONOMIC OPPORTUNITY

GLOBAL WORKING GROUP
The University of Chicago 1126 E. 59th Street Box 107 Chicago IL 60637 


\title{
Persistent privilege? Institutional education gaps during Vietnam's economic boom
}

\author{
Diep Phan 1 and Ian Coxhead2
}

\begin{abstract}
A persistent public-private sector difference in returns to skills is one sign that Vietnam's transition from command to market economy remains incomplete. Matching this is large gap in postcompulsory education enrollments favoring children from families with members employed by government or state enterprises. We compare that gap between 2004 and 2014, a decade during which Vietnam experienced a boom in private-sector and foreign-invested economic activity. Despite the boom, we find a persistent and widening enrollment gap between "state" and "nonstate" households which are similar in other observable respects. This institutional gap is not the only basis for enrollment differences - the ethnicity gap has also widened, even as rural-urban disparities have diminished — but they may contribute to slow and unequal progress in overall educational attainment. Unless addressed, enrollment gaps are likely to worsen intergenerational inequality and may reduce long-run economic growth.
\end{abstract}

Keywords: Schooling, developing countries, inequality, state-owned enterprises, Vietnam JEL codes: I24, I25, J24, O15, P23.

1 Associate Professor, Department of Economics, Beloit College. Address: phand@beloit.edu

2 Professor, Department of Agricultural and Applied Economics, University of Wisconsin-Madison. Address for correspondence: ian.coxhead@wisc.edu. Coxhead acknowledges financial support from the Japan Society for Promotion of Science, and the Graduate School for International Cooperation Studies, Kobe University, Japan for providing an institutional home as a visiting researcher during the preparation of this paper.

We thank seminar participants at the Midwest Economics Association annual meetings, Tohoku University, Kobe University, the Institute for Developing Economies, and the University of Wisconsin-Madison for helpful comments on earlier drafts, and Nguyen Vuong for excellent research assistance. 


\section{Introduction}

Vietnam's economy is a stellar performer in the developing world. It has grown rapidly for more than one generation and poverty, once widespread, has fallen dramatically. Even more impressively, Vietnam's growth boom has not been accompanied by a rapid rise in income inequality as in many other countries. The Gini index for aggregate expenditure inequality has remained stable (Figure 1). This stability is widely attributed to sustained rapid growth in wage labor opportunities and spatial labor mobility, which has limited growth of the urban-rural earnings gap, and investments in human capital that have leveled the rural-urban playing field for new job market entrants (e.g., Benjamin, Brandt, and McCaig 2017).

Figure 1 here

Despite these positive signs, some gaps are not evident in aggregate data. As in many countries, the main dimensions of inequality are either spatial (i.e., regional or rural-urban differences) or are based on ethnicity or race. Vietnam also displays these dimensions, especially the latter (Kozel 2014). But in addition, for structural reasons that we will explore below, in Vietnam (as in China, another transitional economy) there remain large gaps in earnings and opportunity between households that are, or are not, privileged by connections to state employment and institutions. While there is no reason to disagree with the assessment that overall inequality has not increased, we ask in this paper whether that is true over all social divisions, and whether Vietnam's inequality can be expected to remain low in the future. Most studies on Vietnam's inequality focus, appropriately, on the relative worsening of conditions for households in the bottom of the income distribution - in particular, ethnic minorities and inhabitants of remote regions (Nguyen H. 2018, World Bank 2014, Imai et al. 2007, Pham and Reilly 2009). The fault line that is our focus here, that between "state" and "non-state" households, has received far less attention. The approach and findings of this paper build on our own earlier work (Phan and Coxhead 2013; Coxhead and Phan 2013), in which we documented a large education gap between state and non-state households during Vietnam's early transition away from command economy policies in the 1990s and early 2000s. In the present paper we find that in the subsequent decade from 2004, despite a boom in private sector growth, this gap has been persistent and has even become more pronounced. In particular, we find that children from state-connected households remain much more likely to enroll in upper secondary school (grades 10-12) and in tertiary education even after controlling for other observable differences in permanent and transitory income. This educational achievement gap both reflects and 
perpetuates non-market rationing of state-sector jobs, many of which are said to provide access to rents beyond the nominal salary earned. In the future it may contribute to rising income inequality.3

\section{The economic context}

Vietnam's reforms and growth

Like China and other socialist-bloc economies before transition, Vietnam's economy prior to doi moi was centrally planned, its agriculture collectivized, and its state firms and industries subsidized. As is well known, the lack of incentives and the repression of a dynamic private sector in such systems produced disastrous economic results. Vietnam was no exception, and by the mid-1980s was in a deep economic crisis, whose severity created pressure for structural reform. Reform began in the mid-1980s with agricultural price reforms but its scope broadened over the next two decades to include macroeconomic adjustment and stabilization, transition to a mixed-market economy, and lowering of barriers to international trade and foreign investment. Capping this process, in 2007 Vietnam was finally admitted to membership in the World Trade Organization.

The economic results of doi moi were truly remarkable. The economy soon stabilized, and per capita GDP growth has exceeded $4 \%$ in almost every year since 1992. Per capita income, measured on a PPP basis, rose from $15 \%$ of the world average in 1990 to $39 \%$ in 2016. Growth has been strongly pro-poor in the sense that both the poverty headcount and poverty intensity have decreased dramatically. Other fundamental indicators of wellbeing such as infant and child mortality have likewise showed significant improvements. In education, elementary and lower-secondary school enrollment rates have also risen to virtually $100 \%$.

3 Given Vietnam's low Gini ratio, it may seem alarmist to invoke comparisons with the historical experience of former European colonies in Latin America. However, there are some strong parallels in type if not in degree between those resource-extracting colonial societies and the modern Vietnamese state. Notably, the use of rents by one group to secure its hold over political power, and consequent inequality in education and access to capital, are similar if not directly comparable. In Vietnam's modern economy, access to rents is strongly identified with the state and state-controlled entities. As Engerman and Sokoloff (2002) have argued, inequality in control over productive endowments can sustain the development of institutions that deepen and perpetuate inequality - and may harm longrun growth in the process. 
The foregoing general description of Vietnam's successful transition is familiar to all who study that country's economy. However, it obscures many important details about the nature of the reform process, especially regarding Vietnam's state sector policies, to which we now turn.

The doi moi era can be roughly divided by decades. In the early period of reform in the 1990s, despite many trade and market liberalization policies, the government retained a dominant role in economic activity. As in China, the preservation and protection of state-owned enterprises (SOEs) was a central tool of this policy. SOE reform began as early as 1991 but proceeded very slowly until the late 1990s. Private sector commercial activity was only gradually legalized through this decade. Commercial policies during this period continued to be highly biased against the private sector and in favor of the state sector (Athukorala 2006). Among the advantages enjoyed by state firms, a few in particular stand out. First, many firms enjoyed legal monopoly status (or significant regulatory advantages over potential competitors), especially in sectors considered to have strategic or political significance, such as transportation, banking, finance and insurance, education, energy supply and distribution and other infrastructure services, telecommunications, mining, mineral processing and heavy industry, and international trade. Second, all SOEs enjoyed privileged access to capital and below-market rates from the state banking system, with virtually no prudential oversight. Third, due to restrictions on private sector activity, nearly all inward FDI during the 1990s was channeled into state firms or joint ventures with SOEs. A large share of this FDI was aimed at taking advantage of SOEs' monopoly status or was for tariff-jumping purposes rather than targeting Vietnam's areas of comparative advantage, which included agriculture, fisheries, and labor-intensive manufacturing industries.

Thanks to their privileged access to capital, SOEs occupied the most capital-intensive areas of economic activity; thanks to biases in commercial policy, they specialized in nontradable services and importcompeting industries. Being capital-intensive, their propensity to create jobs was low per unit of capital invested, and those jobs were, on average, much more skill-intensive (or at least, more demanding of educational credentials) relative to the capital-starved private sector. And being oriented toward the domestic market, growth in SOE output (and thus in SOE jobs) was largely keyed to the overall growth rate of the economy. In contrast, the vast majority of new jobs were created by private firms, most of which remained small-scale and specialized in labor-intensive and low-productivity activities-especially those in the informal sector. Formal industrial output by the private sector during this period was virtually non-existent (Perkins, Dwight and Vu 2009). 
SOE reforms in the late 1990s aimed to "clean up" by forcing consolidation and some rationalization; this led to the retrenchment of about one million workers from SOEs that were either abolished, merged or made smaller. Despite this, however, the state sector in Vietnam actually expanded its role and size in certain aspects. The reform process eliminated smaller non-performing SOEs but concurrently created large state-owned conglomerates called General Corporations. These Corporations retained (and still retain) control over many strategic industries.

In the later period of reform in the 2000s, the country continued to deepen its integration with the global economy through trade liberalization and other measures. In 2007, after a protracted accession process, Vietnam joined the WTO. To gain accession it had to agree to many conditions; these created substantial opportunity for expansion by private firms, especially in tradable sectors and with increasingly unfettered access to foreign capital. With the passage of a new Enterprise Law in 2000 and its substantive expansion in 2005, the government removed many obstacles faced by Vietnamese private firms, encouraging further entrepreneurial efforts. The result was a dramatic expansion of private sector activity, albeit from a very low base. In the 2000s, FDI started to go into private firms producing in areas of Vietnam's comparative advantage, i.e., labor-intensive manufacturing and food processing for export. Both industrial output and exports by the private sector recorded rapid growth during the 2000s (Perkins, Dwight and Vu 2009). However, these reforms and the process of WTO accession had much less influence on nontradable sectors and virtually none on the domestic capital market, which continued to heavily favor-and subsidize-lending to state firms.

At first glance, it seemed that the government was implementing neoliberal reform in the 2000s. But a closer look reveals sharp sectoral and policy distinctions between private and state sector activities, such that much of growth boom actually help consolidate the power of the state and strengthened SOEs' dominance (Painter 2005). Privatization of state firms has continued, but at a surprisingly slow rate. Much of this activity, moreover, has in fact consisted of the purchase of SOE shares by other SOEs or by state agencies. The General Corporations continue to either receive direct capital from the government or have easy access to capital from state banks. Some have expanded in both size and scope, diversifying even into sectors far removed from their core mandates. Moreover, and in spite of top-level policy attention to improving SOE management and efficiency clamping down on corruption (Brown 2017), the state sector remains large, inefficient, corrupt, and nepotistic. 
Impacts on labor markets and educational investments

The dominance of the state sector has strong implications in the labor market and also in households' decisions to invest in education. State firms receive cheap credit from Vietnam's state banking system, and this enables them to become highly capital-intensive in their choice of technique relative to the economy's overall factor endowments. Moreover, because capital and skills are complementary production inputs, state firms therefore also employ more skill-intensive technologies. However, hiring of skilled workers is limited, because few of these firms produce for the world market. SOE growth is constrained by domestic demand and especially by government spending, which has increased less quickly than exports. As a result, the combination of slow expansion and high rents per job in the public sector has produced an informal job-rationing system. Anecdotal evidence suggests that the price of entry to a state sector job can be as high as one or two years of salary. Job rationing also generates rents that add to the incomes of white-collar workers in government and SOEs.

Alongside this, Vietnam's private sector has experienced far higher borrowing costs and more difficulty gaining access to loans from the commercial banking system despite acting as the engine of employment growth. Facing higher costs to upgrade and expand capital and technology, most private firms remain low-tech, smaller, and less formal. As a result they attract, and employ, mainly workers with lower educational qualifications and offer far lower returns to educational attainment (Phan and Coxhead 2013). Moreover, the globalization of the Vietnamese economy has created far greater growth rates in private sector output (and thus employment) than in SOEs. Vietnam's exports are almost all generated by private firms, some in partnership with or wholly owned by foreign investors. The ratio of exports to GDP has grown from less than $10 \%$ in 1990, at the start of doi moi, to over 50\% in 2015.4 Export growth has exceeded GDP growth - to which the output of most SOE-dominated sectors is proportional — by a factor of more than two. The composition of exports has undergone equally dramatic change, with manufactures - overwhelmingly, low-tech, labor-intensive assembly — rising from $45 \%$ of exports in the mid-1990s to $76 \%$ in 2015 . However, even though educational qualifications for employment in production-line jobs exceed those for agriculture, the other large export-oriented sector, they remain very low (we document this with data in Section 3). Even large, sophisticated foreign investors such as

4 Calculations from data.worldbank.org. 
Samsung (currently the largest single foreign investor in Vietnam) regard the completion of lower secondary school (that is, $9_{\text {th }}$ grade) as sufficient for production-line workers (Financial Times 2019). Institutional, technological and market access differences between Vietnam's state and private subeconomies, and the discrepancy in their growth rates, may help us understand contemporary patterns of variation in upper-high school and tertiary educational attainment.

First, returns to investments in schooling, having risen rapidly (from a very low base) during the earlier reform period, show clear signs of having levelled off and even fallen during Vietnam's boom in laborintensive tradable sector activity (Phan and Coxhead 2013; Tinh, Tran and Le 2016; Demombynes and Testaverde 2017). Lower returns to schooling may have many causes, including increases in the relative supply of more educated workers, but there is no evidence that this is the dominant influence in Vietnam's case, where the average adult worker still has less than eight years of schooling.5 Several studies link the increased prevalence of manufacturing sector jobs to a lower skill premium (Fukase 2013; McCaig and Pavcnik 2018) and a higher propensity for teenage children to be out of school (Coxhead and Shrestha 2017), echoing similar findings in other emerging market economies such as Mexico (Atkin 2016) and Bangladesh (Robertson et al. 2020). Vietnam's comparative advantage in low-skill, laborintensive industries may have induced an across-the-board reduction in expected returns to schooling investments beyond the level required for basic literacy—or at least, reduced the rate at which expected returns rise along with economic growth.

Second, individual expectations of returns to schooling at upper-secondary and tertiary levels are contingent on heterogeneous expectations of state employment. For wage earners, state sector jobs (which account for only $10 \%$ of paid employment) return 5-9 percent in additional earnings per year of education, compared with 3-4 percent per year in non-state employment (Phan and Coxhead 2013). Upper-secondary school curricula are very strongly geared toward college preparation, with the consequence that the wage premium of schooling that terminates at grade 12 over that for grade 9 is negligible. Family connections are strong predictors of employment in state firms (Phan and Coxhead 2013), so for the majority of students who lack such connections, the benefit-cost ratio of an additional year of education beyond lower secondary school is much less. Schooling costs can be a major financial burden on families, so segmentation of the skilled labor market raises the dropout rate among students

5 Source: barrolee.com. 
who do not expect to have access to state sector jobs. This results in a lower overall rate of schooling beyond grade 9 .

Third, and as a consequence, families with connections to state-sector employment should be expected to invest much more heavily in both the quantity and the quality of their children's education, other things equal. In earlier research we found that in 2002-06, the university enrollment probability of a potential student whose household head works in the state or government sector is $1.3-1.4$ times greater than that of someone whose household head works in the private sector. In what follows we take advantage of data from the more recent economic boom to ask whether these disparities have persisted as the Vietnamese economy has grown and changed.

\section{Descriptive statistics}

\section{Data}

Our primary data sources are the 2004 and 2014 rounds of the Vietnam Household Living Standards Survey (VHLSS). These surveys gather data on household income and expenditure and are designed to measure living conditions and poverty and inequality. Their sampling design is representative at national and provincial levels. They also include modules on education and on employment and wages. The sample size in 2004 was 9,188 households, and in 2014 it was 9,399 households. Importantly, the decade from 2004-2014 brackets a period of very rapid economic growth accompanied by extensive liberalization in Vietnam's policies governing trade, foreign investment and commercial policy as the country conformed to WTO rules and bilateral commercial access demands ahead of WTO accession. In general, we define a state household as one that has at least one member who reports working for a state entity. The employment section of VHLSS asks each respondent who is working to identify the organization that employs them in their primary job, with "State-owned economic sector" (2004) or "State-run" (2014) as one option. The contrast between state and non-state households so defined is substantial as following survey of data will make clear. However we also find an important distinction between two types of state employee. Following the question about their employer, the VHLSS questionnaire then asks respondents whether or not they are public employees or civil servants.6 Among

6 These questions are section 4, questions 10a and 10b in VHLSS 2004, and section 4, questions 8a and 8b in 2014. 
workers for state entities, this distinction is very meaningful in terms of education and occupation. Table 1 compares educational and occupational distributions for both kinds of state employees and also for nonstate employees, in 2014. Workers for state entities that are also classed as civil servants or public employees, relative to those not so described, have considerably greater educational attainment. In 2014 two-thirds of this group (whom we describe as "managerial" state employees) possessed tertiary educational credentials as opposed to $24 \%$ for other state employees. Both kinds of state employees have greater average educational attainment than non-state employees, including those employed by foreigninvested firms. In terms of occupations, $79 \%$ of the first group of state employees work as "leaders, managers or experts" (in the VHLSS terminology) while in the second state group, 70\% have nonmanagerial jobs including lower-level white collar work, clerical, sales, and various types of skilled and unskilled production jobs.7 As with education, the occupational distribution for both types of state employee differs markedly from that of non-state workers, whether employed by domestic or foreign firms, more than four-fifths of whom are employed in agriculture or manual trades.

Table 2 shows summary statistics for the main variables of interest in our statistical analysis, for the full sample, for non-state households and each type of state household. These show that the three household types are indeed very different. State households on average have higher income and are more likely to live in urban areas; their heads have higher average years of schooling 8 and are more likely to hold a skilled or professional job. Our investigation of the influence of state sector links to schooling must control for these differences, as well as those between the two types of state household. To avoid excessive detail, however, in the remainder of this section we focus only on the broader state-nonstate distinction.

$7 \mathrm{Vu}$ and Yamada (2020) explore trends in earnings between state and non-state workers in the VHLSS data and find that salary premia for state workers have diminished over time. However, their definition of "state" is constructed only from members of the non-managerial group as we have defined it.

8 To measure years of education, many studies have used the VHLSS's original schooling year variable. This is based on categorical indicators which are then concatenated into a cardinal index with values ranging from 0 (no education) through 12 (higher degree). The disadvantages of that concatenation are obvious. We opt to convert levels of schooling into implied years of schooling based on expected number of years required to complete each level. In 2014, $78 \%$ of household heads reported 9th grade or lower educational attainment. 
Table 2 here

Income differences between state and non-state households

To examine changes in income differences for groups of households we compare income ratios, and also computed and decomposed Gini indices. Although total inequality in Vietnam has been relatively stable, the sources of inequality have changed. In 2004 a significant share of total inequality was due to urbanrural differences, but this diminished through the ensuing decade. Figure 2 shows that the ratio of income per capita in urban households to that in rural households narrowed from 1.95 in 2004 to 1.67 in 2014. Meanwhile, the state to non-state per capita income ratio increased slightly from 1.67 to 1.74 , and the ratio of kinh (ethnic majority, about $83 \%$ of population) to ethnic minority household incomes increased from 1.87 to 2.08. Table 3, which shows a decomposition of the Gini for per capita income, confirms a similar trend. The contribution of differences between urban and rural households to total inequality has gone down from $32 \%$ in 2004 to $29 \%$ in 2014, while the contribution of differences between state and non-state households to total inequality has risen, from $17 \%$ in 2004 to $22 \%$ in 2014 . The contribution of differences between kinh and minority households has also risen, from 12\% in 2004 to $17 \%$ in 2014 .

Table 3 here

Figure 2 here

Figures 3 and 4 summarize income differences between state and non-state households. These show density plots of the log of household income. The state household income distribution lies everywhere to the right of the nonstate distribution, both in 2004 and in 2014. Restricting the sample to urban households only (where state households are concentrated) does not substantially alter this pattern.

Figures 3 and 4 here

\section{Educational attainment differences between children of state and non-state households}

Overall, children of urban, state, and kinh households have higher educational attainment than children of rural, non-state, and minority households, as seen in Figures 5-7. Figure 5 shows that in 2014, children of state households start dropping out of school at the age of 15, while children of non-state households start dropping out three years earlier at the age of 12. Similarly, there is a dramatic drop in school attendance rate of ethnic minority children right around the age of 12, about $2-3$ years earlier than that of kinh children (see Figure 7). 
Figures 5 - 7 here

From 2004 to 2014, there were changes in differences in educational attainment among children of various household groups. Figures $2 \mathrm{~b}$ and $2 \mathrm{c}$ revealed that changes in inequality of educational attainment mirrored the trend in income inequality described earlier. In the decade from 2004 to 2014, the urbanrural difference in college enrollment rate increased very little, and the difference in high school enrollment rates actually decreased. During this same decade, state-non-state differences in both college enrollment rate and high school enrollment rate increased quite perceptibly. The widening difference between kinh and minority groups was even more dramatic, especially for high school enrollment.

\section{Empirical analysis}

\section{Determinants of upper secondary and tertiary enrollment}

In 2004-14, compulsory education in Vietnam ended at sixth grade and a large fraction of schoolchildren terminated their schooling no later than 9 th grade (about age 15). A smaller number enrolled in upper secondary school (10-12th grade) and fewer still proceeded to tertiary education. Those who did were overwhelmingly from upper-SES families and were destined for jobs in the public sector.

However educational credentials, while necessary, but may not be sufficient for entry to state sector employment. Due to job-rationing connections are also necessary for many applicants (Phan and Coxhead 2013). Children of some state households have familial connections that make it easier for them to obtain state sector jobs and access rents in this sector. We hypothesize that state households invest more in the education of their children, with the goal of ensuring that they have the required educational credentials. This hypothesis received support in our earlier work using VHLSS data up to 2006 (Coxhead and Phan 2013). There, in a logit regression examining the determinants of the probability of school enrollment we found that the state sector dummy was positive and statistically significant. In this paper, we return to the same question using a decade-long comparison from the economic boom spanning WTO accession. We are interested in knowing whether the effect of state sector employment remains significant, and whether its magnitude has increased or decreased relative to the earlier estimates. As discussed in section 2, we know that meaningful reform of the state sector has lagged. However, private sector activity has grown very fast. In addition, a few of the more successful SOEs were "equitized" (effectively privatized) during the decade covered by our data. Their addition to the stock of private sector firms should have raised the overall capital intensity measure, other things equal. Moreover, if private sector development has also 
become more intensive in capital and skills, as might be expected given capital deepening, then we should see additional closing of the state to non-state educational enrollment gap.

To evaluate influences on educational enrollments we propose a probit model:

$$
\operatorname{Pr}\left(Y_{i j}=1 \mid \mathrm{X}_{i j}\right)=\Phi\left(\mathrm{X}_{i j}^{T} \beta\right)+\varepsilon_{i j}
$$

where $Y_{i j}$ is the probability that child $i$ aged 15-22 in household $j$ is enrolled in education (either high school or college). The vector $X$ contains the variable of interest $S_{j}$, a dummy equal to one if the household has at least one member working for the state. Other elements of $X$ are the household's currentyear income and variables measuring its permanent income: these include parental education and location of residence. Still other elements are demographic features of the household such as ethnicity, the age of the household head and the number of adults present. Lastly, we control for age and sex of the child. We estimate this model separately for 2004 and 2014, and for children of upper-secondary age as well as tertiary age, and compare results over years.

It is important to point out that it is not our goal to explain educational gaps over the entire schooling experience. As mentioned, many young Vietnamese choose to terminate their education at or before grade 9. Our concern is with children who have completed this level of schooling. We focus on explaining upper secondary school enrollment conditional on lower secondary (grade 9) completion, and tertiary enrollment conditional on upper secondary school (grade 12) completion. This censoring disproportionately removes students from households with incomes below the median from our sample. Indeed, Table 4 shows that children who did not finish middle school or high school come from households with lower average income; are more likely to belong to ethnic minority groups, and are less likely to live in urban areas. As a result, our parameter estimates will understate the impacts of variables strongly correlated with poverty, of which the most important by far is ethnic minority status.9 On the other hand, by restricting the sample in this way we greatly reduce its heterogeneity. This will reduce the power of hypothesis tests on educational differences within the remaining sample; any rejection of the null hypothesis of no differences will therefore be more meaningful.

9 Headcount poverty among the kinh (ethnic majority) population fell from 53\% in 1993 to just 6\% in 2014. Among ethnic minorities, however, poverty incidence declined far less: from $86 \%$ in 1993 (comprising 20\% of the poor) only to $58 \%$ in 2014 (comprising $60 \%$ of the remaining poor (Kozel 2014)). 
Table 4 here

At each level of schooling and in each year, the result of interest is the estimated effect of state employment by a household member on the probability that a child in the same household is in school. Table 5 shows enrollment rates calculated from the data. In 2004, children from state households were more than one-third more likely to be in high school (79\% versus 58\%) and nearly twice as likely to be in college (45\% versus 24\%) as those from non-state households. Those differences changed by 2014 but not by much, and the high school enrollment gap actually increased due to a much sharper rise in the fraction of state-household children enrolled. The final column of the table shows a priori odds ratios, defined as the odds of being in school conditional on living in a state household, divided by the odds of being in school conditional on living in a non-state household.10 From the table we see that the calculated odds ratios for high school enrollment rose from 2.7 in 2004 to 3.4 in 2014, while those for college enrollment declined slightly, from 2.5 to 2.3 . For high school, the rise in the odds ratio is driven by a 4.7 percentage point increase in enrollments by children from state households, while among non-state households the increase was only 1.3 percentage points. In contrast, college enrollments rose among all households but the odds ratio fell slightly because enrollments from non-state households increased by more (6.7 p.p. versus 5.7 p.p.).

Table 5 here

It seems intuitive to identify household income as a determinant of children's school enrollment and academic performance. We have pointed out that holding a state-sector job is likely to provide access to rents. So it is reasonable to be concerned that a measure of current household income is endogenous to other covariates, including of course employment in a state entity (statistically, this concern may be addressed with an instrumental variables (IV) estimator, and we report IV estimates in an appendix). However, there are other relevant dimensions to this problem. First, current income is probably not a strong contributor to educational decisions after longer-run family economic and social conditions are taken into account. In an influential U.S. study, Cameron and Heckman (1998) confirm that household fixed effects capturing differences in permanent income — such as parental educational attainment, for example - play a more important role in conditioning educational outcomes. In contrast, current-period

10 The odds of each are defined as $p_{i}\left(1-p_{i}\right)$, where $p_{i}$ is the probability that a child drawn from population $i$ is in school. 
earnings "may contain strong transitory components to which family members do not respond" (p.307). Second, in our data household incomes are almost certainly both underreported and mis-measuredespecially among the group of greatest interest. It is likely (and anecdotal accounts confirm this) that many of the benefits of a state sector job do not appear in individual paychecks. Instead, they take the form either of supplementary earnings that may or may not be reported, and/or of non-pecuniary benefits including job security and retirement plans, and/or of influence that can be exerted to secure other benefits - including, but not limited to, jobs for other household members. For these reasons our measures of current-period household income are likely to be noisy, leading to larger standard errors, and may also be systematically undermeasured in the sub-population of greatest interest.

We do not have panel data spanning the years of interest, so cannot use household fixed effects. We do, however, have measures of variables contributing to permanent income (or more generally, long-run socioeconomic status) that typically evolve very slowly (or not at all) over a generation or more. These include, along with parental education, whether or not a parent or other household adult has a state sector job (and the type of job, if so); whether the household resides in an urban location with more ready access to upper secondary schools and tertiary institutions; and ethnicity, since kinh-minority economic disparities have proven very resilient during Vietnam's economic boom. Analogous to permanent income, these variables capture "stocks" of household well-being as opposed to the "flow" of annual household income. To the extent that current income is a function of longer-run variables, its inclusion in a model estimating the propensity for children to be in school or college should bias their effects downwards. In the estimation results reported below, we present as our preferred model one that includes both currentperiod and permanent household income. However, we also compare these against estimates excluding current income as a covariate and our findings are consistent with downward bias.11 More strongly, if current income retains significance as an influence on schooling even after controlling for permanent income, then as Cameron and Heckman argue, it indicates that financial constraints inhibit school attendance. Our estimates show that both the magnitude and significance of the current household income variable in regressions of school attendance are noticeably lower in 2014, after a decade of rapid increase in per capita income and poverty decline, than in 2004.

${ }_{11}$ Our results are consistent with those found elsewhere in the literature, for example Chevalier et al. 2013. 
Table 6 presents probit estimates for high school and college enrollment in 2004 and 2014. The units of observation are individual children of relevant age. In each case the dependent variable is a binary indicator equal to one if the child is enrolled in education and zero otherwise. Coefficient estimates of demographic controls of secondary interest (age and sex of household head, age and sex of child, number of children in household) are omitted to save space. The main results can be summarized as follows.

- Variables associated with permanent income have expected signs and are for the most part strongly significant. Education of the household head, the key variable among these, has expected positive effects and is highly significant. Urban location and ethnic minority status are mostly of expected sign (positive and negative, respectively) and significance. These effects are stable over years: tests of differences in parameter values between 2004 and 2014 failed to reject the null hypothesis of equality in every case but one, that of ethnicity in the high school enrollment model.12

- Presence in the household of a senior (managerial level) state employee has a positive association with in-school status and is significant in three cases out of four. Presence of a state employee below managerial level has no such statistical association (except in one case where it is negative). For households with managerial-level state employees, the marginal effects are large. In 2004, high-school aged children in households with a managerial level state employee were almost ten percentage points more likely to be in school than those without. In 2014, this marginal effect had increased to 17 percentage points. For college enrollments, the 2004 marginal effect was 7\%, rising by 2014 to $17 \% .13$ Tests of parameter stability between 2004 and 2014 show that the coefficient of managerial level state employees is higher in 2014 for high school enrollments with $\mathrm{p}<0.134$, and for college enrollments with $\mathrm{p}<0.04$.

- Current-period household income was significant and positive in 2004 but not in 2014, and the null hypothesis of equal coefficients across years is rejected with $\mathrm{p}<0.02$ for high school and $\mathrm{p}<0.01$ for college. If this variable represents financial constraints after permanent income has been captured through other covariates, then the estimates are consistent with such constraints binding in 2004 but not in 2014, after a decade of rapid growth in per-capita incomes.

12 Test statistics for parameter stability across models are obtained using Stata suest post-estimation command. 13 Complete tables of margins calculations are available from the authors. 
Table 6 here

As discussed earlier, the literature on parental income and children's schooling suggests that inclusion of current-period income together with variables representing permanent income should impart downward bias to estimates of the latter. Table 7 shows estimates of the same probit models as in Table 6, but excluding current period income. The main results are as follows.

- Measures of permanent income (household head education, urban location and ethnicity) retain broadly the same influence as before.

- The contribution of a managerial-level state employee in the household remains strongly positive, and of almost exactly the same magnitude as before. Likewise, coefficient estimates associated with a lower-level state employee remain insignificant in 3 out of 4 cases.

- Coefficient estimates for household head's education are almost identical in both models. Those for urban location and presence of a managerial level state employee are appreciably larger when current-period income is excluded. These results are consistent with the conjecture that including current-period income imparts downward bias to the effects of measures of permanent income.

- Overall goodness of fit (pseudo-R2) is only slightly lower for 2004, and unchanged for 2014.

The minimal reduction in goodness of fit, and the broadly similar coefficient estimates seen between Tables 6 and 7 suggest that the model as specified is robust with respect to inclusion of a household income, a potentially endogenous variable. As a further test, we instrument for household income in a two-stage model. The results (see Appendix) confirm model robustness. In each of the four models fitted, first-stage F-statistics are large (with values greater than 50), indicating that the instruments are valid. More importantly, Wald tests for exogeneity of the instrumented variable fail to reject the null hypothesis in each case, indicating that an IV approach is not merited. Estimates in the IV models are very similar in magnitude and significance to those reported in Tables 6 and 7.

\section{Table 7 here}

To summarize, we conclude from these estimates that households whose adult membership includes at least one managerial-level state employee have significantly higher propensity to educate their children beyond compulsory schooling - and moreover, that this difference became even greater over a decade of rapid economic growth. Recall that these estimates are from a sample that excludes children who have not completed grade 9 -i.e., those from the poorest households. Because of this, and since we are also 
controlling for household characteristics known to be associated with the average educational gap (in particular parental education, location, and ethnicity) it is hard to assert that the statistical significance of this state household indicator captures intrinsic differences in behavior or preferences. It seems more likely that it captures differential assessments of returns to continuing in education beyond mandatory grades. It is certainly possible that state households can use influence to get their children placed in better high schools or in better classes, but if so this is just another expression of the same "connections" that help increase the chances of a state sector job.14 We conclude that despite major changes in the structure of the Vietnamese economy during the 2004-14 period, and in particular economic policy reforms and investments that promoted rapid private sector growth, the pace and extent of change has been insufficient to materially diminish the relative value of rents associated with working in government and in the country's most protected, least competitive firms, those in the state-owned sector.15

\section{Policy discussion}

This foregoing empirical results can be summarized as follows. In 2004, connections to the state sector played an important role in determining whether a child continued with high school. Children from families with such connections were about twice as likely to be enrolled in high school as those from families lacking state connections. Ten years later, even after a decade of rapid growth and marketopening reform, the importance of these connections had diminished only slightly in magnitude and remained significant, even after controlling for other evolving household characteristics such as income and parental education. Meanwhile, by 2014 a large and significant state-nonstate gap had opened up in tertiary enrollments; about 50\% of 18-23 year-olds from state households were enrolled in tertiary education, against about $30 \%$ from non-state households. Together, these results point to a robustly persistent gap in educational investments in the children of state and non-state households. These results are consistent with persistent distortions in labor market and educational investment decisions induced by

14 It is also possible that Vietnam's booming private sector wealth is leading to a disproportionate increase in the propensity for non-state families to send their children overseas for high school and college. Vietnamese students are the fastest-growing foreign student population in several large education-exporting countries, including the United States.

15 The persistence of rents in these sectors is undoubtedly correlated with other practices that reduce transparency, productivity and dynamism. Perceptions of this correlation almost certainly explain the repeated failure of efforts to float shares in partially privatized SOEs to private investors. See, for example, Coxhead (2018). 
Vietnam's state sector policies (as explained in section 2) even in spite of very rapid growth in non-state economic activity.

What are the implications of finishing school early for teenagers from disadvantaged households, i.e., poor households without connections to the state sector, or members of ethnic minority groups? On the one hand, beyond the age of 15 they may legally work and earn, so the opportunity cost of additional schooling may be high in addition to its direct costs. On the other hand, resources for adult or continuing education are very scarce in Vietnam as in nearly all middle-income countries - a contrast with wealthier countries, where a surprisingly large fraction of adults re-enter the educational system in pursuit of credentials and non-formal training (OECD, 2014). As a result, virtually the only skills that can be acquired after leaving school are those learned on the job. In blue-collar employment, which is where middle-school graduates find themselves, these opportunities are minimal in Vietnam. So the decision to end schooling at or below 9th grade places children on a career path that will typically not rise above lowwage employment. They are far more likely than better-educated workers to be informally employed; more susceptible to income loss through injury or illness; and in faster growing economies like Vietnam, more vulnerable to job loss as they age out of the target workforce or as "footloose" industries relocate to lower-cost countries. Moreover, the disadvantages that they face will be inherited, in part, by their own children - just as those in the current generation with a poor start in life suffer accumulating disadvantages as they move through the school system. In our estimates, we see a strengthening of the intergenerational transmission of educational attainment in the form of larger coefficient estimates of parental education on children's probability of being in high school or tertiary training.

Vietnam's government has demonstrated a firm commitment to schooling as a tool for promoting growth and reducing inequality. Education accounts for about $20 \%$ of government expenditures. Aggregate statistics show great improvements overall in school access, literacy, and primary enrollments, and reasonable progress toward more ambitious goals of universal middle and high school education. The country also boasts some headline accomplishments, including an almost unrealistically high global ranking on some standardized tests.16 But abundant evidence of an education achievement gap remains. This will likely hamper long-run economic growth and might cause inequality to start rising again.

16 http://www.oecd.org/pisa/ 
How can Vietnam deal with its remaining education gaps? A first-best policy step would be to remove state sector preferences that distort the labor market and households' educational investment decisions. Beyond that, there is surprisingly no consensus - in Vietnam, or elsewhere — on how best to reduce education gaps when resources are limited. This is because of ongoing uncertainty about the critical reasons for differences in schooling outcomes for sub-populations. These could be due to poverty, lack of access to schools and educational resources, the opportunity costs of schooling in an economy increasingly specialized in labor-intensive manufacturing for export, or group-specific characteristics including, potentially, some forms of social or economic discrimination. Where the differences arise, and what form they take, has implications for the kinds of policies that will have greatest chances of success. Vietnam's boom in private and foreign-invested enterprise activity is ongoing. Anecdotally, it seems clear in 2019 that in many professions the advantage of working for government or state-controlled enterprises has diminished. The benefits offered by government and state corporations - job security, retirement plans, health care, and non-salary earning opportunities — are increasingly matched or at least compensated by foreign-invested firms seeking to hire tertiary-educated workers from Vietnam's stillshallow talent pool. With the passage of time, therefore, the state-nonstate education gap may die a natural death. But the conditions for that to occur, and the period over which it might do so, are unknowns subject to many other variables - including, importantly, state capacity and political will to reduce the prevalence of corruption and influence-dealing.

\section{Conclusions}

Improved educational attainment is the first and most important step toward a long-term solution to differences in levels of living and in economic opportunity. In many other fast-growing southeast and east Asian economies, inequality rose sharply in the first two decades of the 21 st century. Much of the blame has been attributed to inequality of opportunity, with access to schools and educational opportunities high on the list. In Vietnam, aggregate measures of inequality remain lower and have risen more slowly than in neighboring countries. The urban-rural income gap has narrowed as labor migration has blurred this geographical distinction for those able to move. Yet other dimensions of inequality, notably those based on ethnicity and on household connections to the privileged state sector, have proved remarkably robust even as the structure of production, employment and incomes has changed. Focusing on the trend in

inequality between state and non-state households, we find in this research that gaps in enrollment rates of children and young adults beyond ninth grade, remained robustly significant and even increased in 
magnitude throughout a decade of very rapid economic growth. Without further progress on economic reform, there is no guarantee that this dimension of inequality in Vietnam will not increase in the future, as growth and structural change continue apace while large parts of the economy remain beset by significant distortions. 


\section{References}

Athukorala, P. 2006. "Trade policy reforms and the structure of protection in Vietnam." The World Economy 29(2): 161-87

Atkin, David, 2016. endogenous skill acquisition and export manufacturing in Mexico. American Economic Review 106(8): 2046-2085.

Benjamin, D., L. Brandt, and B. McCaig, 2017. "Growth with equity: income inequality in Vietnam, 2002-14.” Journal of Economic Inequality 15(1): 25-46.

Brown, D. 2017. "Vietnam's conservatives purge former PM Dung's allies," Asia Sentinel, September 18, 2017, <http://www.asiasentinel.com/politics/vietnam-conservatives-purge-former-pm-dungs-allies/>, accessed October 1, 2017.

Cameron, S.V.; and J.J. Heckman, 1998. "Life cycle schooling and dynamic selection bias: models and evidence for five cohorts of American males." Journal of Political Economy 106(2):262-333.

Chevalier, A.; C. Harmon, V. O'Sullivan and I. Walker, 2013. "The impact of parental income and education on the schooling of their children." IZA Journal of Labor Economics 2,8.

https://doi.org/10.1186/2193-8997-2-8.

Coxhead, I. and D. Phan, 2013. "Princelings and paupers: State employment and the distribution of human capital investments among Vietnamese households." Asian Development Review 30(2): 26-48.

Coxhead, I. and R. Shrestha, 2017. "Globalization and school-work choices in an emerging economy: Vietnam.” Asian Economic Papers 16(2): 1-18.

Coxhead, I., 2018. "Vietnam in 2017: Flying fast in turbulence." Asian Survey 58(1), 149-157.

Demombynes, G., and M. Testaverde, 2017. Employment structure and returns to skill in Vietnam: estimates using the Labor Force Survey. World Bank.

Dinh Vu Trang Ngan, 2015. The young people of Vietnam and how they see the world. Ph.D. dissertation, Darwin College, Cambridge University.

Engerman, S.L., and K.L. Sokoloff, 2002. "Factor endowments, inequality, and paths of development among new world economies." NBER Working Papers No. 9259.

Financial Times, 2019. "Vietnam gains ground in shift from China." 17 September 2019.

Fukase, E., 2013. "Export liberalization, job creation, and the skill premium: evidence from the USVietnam Bilateral Trade Agreement (BTA). World Development 41: 317-337.

Han, J., Q. Zhao, and M. Zhang, 2016. “China's inequality in a global context.” Perspectives in Science 7: 24-29.

Hosmer, D.W., and S. Lemesbow, 1980. "Goodness of fit tests for the multiple logistic regression model." Communications in Statistics - Theory and Methods 9(10): 1043-1069.

Imai, Katsushi \& Gaiha, Raghav \& Kang, Woojin, 2007. "Poverty, inequality and ethnic minorities in Vietnam." International Review of Applied Economics. 25. 249-282. 10.2139/ssrn.1205122.

Kozel, V.J. (ed.), 2014. Well Begun but Not Yet Done: Progress and Emerging Challenges for Poverty Reduction in Vietnam. Washington, DC: World Bank Group.

McCaig, B., and N. Pavcnik, 2018. "Exports markets and labor allocation in a low-income country." American Economic Review 108(7): 1899-1941. 
Nguyen, H. T. M. 2018. "Ethnic gaps in child education outcomes in Vietnam: an investigation using Young Lives data.” Education Economics DOI: 10.1080/09645292.2018.1444147

Painter, M., 2005. "The politics of state sector reforms in Vietnam: contested agendas and uncertain trajectories." The Journal of Development Studies 41(2): 261-83.

Perkins, D. and Vu, T.T.A., 2009. "Vietnam's industrial policy: designing policies for sustainable development” Harvard Policy Dialogue Paper \#1, Vietnam Program, Ash Institute for Democratic Governance and Innovation, John F. Kennedy School of Government.

Pham, H., B. Reilly, 2009. "Ethnic wage inequality in Vietnam" International Journal of Manpower 30(3): 192-219

Phan, D. and I. Coxhead, 2013. "Long-run costs of piecemeal reform: wage inequality and returns to education in Vietnam." Journal of Comparative Economics 41(4): 1106-1122.

Robertson, R.; D. Kokas, D. Cardozo, and G. Lopez-Acevedo, 2020. "Short and long-run labor market effects of developing-country exports: evidence from Bangladesh." World Bank Policy Research Working Papers No. 9176.

Tinh, D., Tran Q.T. and Le Q, 2016. Lost in transition? Declining returns to education in Vietnam. University of Waikato, Department of Economics, Working Paper 01/16.

$\mathrm{Vu}$, T. M. and H. Yamada, 2020. "Convergence of public and private enterprise wages in a transition economy: evidence from a distributional decomposition in Vietnam, 2002-2014," Economic Systems 44(1): .

World Bank, 2014. Taking Stock: An Update on Vietnam's Recent Economic Developments - Special Focus on Inequality in Vietnam, The World Bank July 2014

<http://documents.worldbank.org/curated/en/641241468133544451/pdf/893100WP0P13240tock0July020 140FINAL.pdf>, accessed March 2018. 
Table 1: Education and occupational status of the labor force, by employer type 2014

\begin{tabular}{|c|c|c|c|c|c|c|}
\hline \multicolumn{7}{|l|}{ A: Education } \\
\hline Employer type & $\begin{array}{c}\text { Incomplete } \\
\text { primary }\end{array}$ & Primary & $\begin{array}{c}\text { Lower } \\
\text { secondary }\end{array}$ & $\begin{array}{c}\text { Upper } \\
\text { secondary }\end{array}$ & Tertiary & Total \\
\hline $\begin{array}{l}\text { State } \\
\text { (managerial) }\end{array}$ & 0.19 & 1.30 & 5.12 & 26.68 & 66.71 & 100.00 \\
\hline State (other) & 4.72 & 11.97 & 19.69 & 39.84 & 23.78 & 100.00 \\
\hline Foreign & 23.03 & 13.82 & 23.60 & 26.85 & 12.70 & 100.00 \\
\hline Other private & 35.71 & 24.77 & 23.04 & 13.48 & 3.00 & 100.00 \\
\hline Total & 33.33 & 23.27 & 22.22 & 14.84 & 6.33 & 100.00 \\
\hline \multicolumn{7}{|l|}{ B: Occupation } \\
\hline Employer type & $\begin{array}{l}\text { Managers } \\
\text { and } \\
\text { experts }\end{array}$ & $\begin{array}{l}\text { Tech- } \\
\text { nicians/ } \\
\text { teachers }\end{array}$ & $\begin{array}{c}\text { Clerical/ } \\
\text { sales }\end{array}$ & $\begin{array}{l}\text { Skilled workers } \\
\text { in agric. }\end{array}$ & $\begin{array}{c}\text { Other manual } \\
\text { workers }\end{array}$ & Total \\
\hline $\begin{array}{l}\text { State } \\
\text { (managerial) }\end{array}$ & 51.84 & 26.73 & 12.17 & 1.04 & 8.22 & 100.00 \\
\hline State (other)* & 18.08 & 12.58 & 29.09 & 5.82 & 34.43 & 100.00 \\
\hline Foreign & 6.97 & 3.03 & 6.40 & 0.34 & 83.26 & 100.00 \\
\hline Other private & 0.86 & 0.54 & 8.30 & 5.54 & 84.76 & 100.00 \\
\hline Total & 3.50 & 1.94 & 8.78 & 5.22 & 80.56 & 100.00 \\
\hline
\end{tabular}

Source: Authors' calculations from VHLSS.

Notes:

State (managerial) and state (other) are as defined in the text. "Foreign" is workers employed by foreign-invested enterprises. "Other private" is all employees and self-employed workers not included in the foregoing categories.

Occupation categories correspond to coded values in VHLSS 2014 as follows: Managers and experts 10-29;

Technicians and teachers 30-39; Clerical and sales 40-59; Skilled workers in ag. 60-69; Other manual workers 7099. Military personnel included in last category.

In 2014 the frequency of each category is: State (managerial) 1,545; State (other) 636; Foreign 890, and Other 33,010 . 
Table 2: Summary statistics of key variables used in estimation

\begin{tabular}{|c|c|c|c|c|c|c|c|c|}
\hline \multirow[t]{2}{*}{ Variable } & \multicolumn{2}{|c|}{ Nonstate } & \multicolumn{2}{|c|}{$\begin{array}{c}\text { State } \\
\text { (Managerial) }\end{array}$} & \multicolumn{2}{|c|}{$\begin{array}{l}\text { State } \\
\text { (Other) }\end{array}$} & \multicolumn{2}{|c|}{ All } \\
\hline & mean & s.d. & mean & s.d. & mean & s.d. & mean & s.d. \\
\hline \multicolumn{9}{|l|}{2004} \\
\hline In-school rate & 0.29 & 0.455 & 0.33 & 0.469 & 0.27 & 0.444 & 0.30 & 0.456 \\
\hline Log of $\mathrm{HH}$ income & 9.88 & 0.686 & 10.51 & 0.568 & 10.39 & 0.642 & 9.99 & 0.709 \\
\hline HH head educ yrs & 6.25 & 3.619 & 10.30 & 4.032 & 8.56 & 3.818 & 6.91 & 3.946 \\
\hline Urban resident & 0.18 & 0.384 & 0.48 & 0.500 & 0.45 & 0.498 & 0.23 & 0.424 \\
\hline Ethnic minority & 0.20 & 0.397 & 0.14 & 0.342 & 0.10 & 0.301 & 0.18 & 0.386 \\
\hline \multicolumn{9}{|l|}{2014} \\
\hline In-school rate & 0.24 & 0.429 & 0.26 & 0.440 & 0.23 & 0.419 & 0.25 & 0.430 \\
\hline Log of $\mathrm{HH}$ income & 11.28 & 0.761 & 12.06 & 0.523 & 11.79 & 0.611 & 11.41 & 0.777 \\
\hline HH head educ yrs & 6.83 & 3.867 & 11.92 & 4.110 & 9.09 & 4.017 & 7.61 & 4.281 \\
\hline Urban resident & 0.25 & 0.431 & 0.51 & 0.500 & 0.51 & 0.500 & 0.29 & 0.456 \\
\hline Ethnic minority & 0.22 & 0.412 & 0.12 & 0.322 & 0.11 & 0.311 & 0.20 & 0.398 \\
\hline
\end{tabular}

Source: Authors' calculations from VHLSS.

Note: other demographic variables used in estimation do not vary appreciably across groups and are not reported. 
Table 3: Inequality of per capita income

\begin{tabular}{|c|c|c|c|c|}
\hline & \multicolumn{2}{|c|}{2004} & \multicolumn{2}{|c|}{2014} \\
\hline & $\begin{array}{c}\text { Gini } \\
\text { Index }\end{array}$ & $\begin{array}{c}\% \\
\text { contribution } \\
\text { to total } \\
\text { inequality } \\
\end{array}$ & $\begin{array}{c}\text { Gini } \\
\text { Index }\end{array}$ & $\begin{array}{c}\% \\
\text { contribution } \\
\text { to total } \\
\text { inequality }\end{array}$ \\
\hline Total inequality & 0.41 & & 0.418 & \\
\hline \multicolumn{5}{|c|}{ Decomposition by urban-rural dimension } \\
\hline Within & 0.213 & 52 & 0.215 & 51 \\
\hline Between & 0.131 & 32 & 0.122 & 29 \\
\hline Overlap & 0.066 & 16 & 0.082 & 20 \\
\hline \multicolumn{5}{|c|}{ Decomposition by state-nonstate household dimension } \\
\hline Within & 0.295 & 72 & 0.295 & 70 \\
\hline Between & 0.071 & 17 & 0.091 & 22 \\
\hline Overlap & 0.043 & 11 & 0.033 & 8 \\
\hline \multicolumn{5}{|c|}{ Decomposition by kinh-minority dimension } \\
\hline Within & 0.315 & 77 & 0.305 & 73 \\
\hline Between & 0.05 & 12 & 0.073 & 17 \\
\hline Overlap & 0.045 & 11 & 0.041 & 10 \\
\hline
\end{tabular}

Source: Authors' calculations from VHLSS. 
Table 4: Comparison: children with and without Grade 9 and Grade 12 completion

2004

Number of children

Annual household income, VND '000 (USD)

$\%$ ethnic minority

$\%$ urban

2014

Number of children

Annual household income ('000 VND)

$\%$ ethnic minority

$\%$ urban

2004

Number of children

Annual household income ('000 VND)

$\%$ ethnic minority

$\%$ urban

2014

Number of children

Annual household income ('000 VND)

$\%$ ethnic minority

$\%$ urban

Upper secondary age (15-18)

\begin{tabular}{ccc}
\hline & $\begin{array}{c}\text { Grade } 9 \text { not } \\
\text { completed }\end{array}$ & $\begin{array}{c}\text { for mean } \\
\text { difference }\end{array}$ \\
\hline
\end{tabular}

2232

1737

29,954 (\$557)

12.80

$26,236(\$ 507)$

4.8

27.80

12.02

23.40

17.60

4.48

1439

840

$117,228(\$ 3732) \quad 101,574(\$ 2705) \quad 2.95$

19.70

28.80

5.02

27.80

24.50

1.76

Tertiary age (18-23)

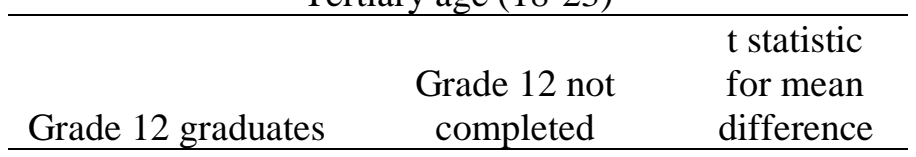

1749

39417 (\$840)

9.00

38.50

1803

140134 (\$3230)

13.60

33.20
2983

$27901(\$ 400)$

24.20

16.22

1807

$111378(\$ 2329)$

33.60

7.2

14.5

23.80
13.9

13.2

17.8

Source: Authors' calculations using VHLSS 2004 and 2014 
Table 5: Enrollment rates, enrollment gaps and a priori odds ratios

\begin{tabular}{lcccc}
\hline & State & Non-state & Enrollment gap, \%a & Odds ratiob \\
\hline High School & & & & \\
2004 & 0.785 & 0.577 & 36 & 2.68 \\
2014 & 0.832 & 0.59 & 41 & 3.44 \\
Change (percentage points) & 0.047 & 0.013 & & \\
& & & & \\
College & & & 85 & 2.53 \\
2004 & 0.445 & 0.241 & 63 & 2.26 \\
2014 & 0.502 & 0.308 & & \\
Change (percentage points) & 0.057 & 0.067 & & \\
\hline
\end{tabular}

a Calculated as $100 *$ (state/non-state) 1 .

b Calculated as $\mathrm{O}_{s} / \mathrm{O}_{n}$, where $\mathrm{O}_{\mathrm{i}}=\mathrm{p}_{\mathrm{i}} /\left(1-\mathrm{p}_{\mathrm{i}}\right)$, and $\mathrm{p}_{\mathrm{i}}$ is enrollment rate of group $\mathrm{i}, \mathrm{i}=\{\mathrm{S}, \mathrm{N}\}$.

Data source: Calculated from VHLSS 2004 and 2014, as described in text.

Table 6: Probability of enrollment in high school or college, 2004 and 2014

\begin{tabular}{lcccc}
\hline & $(1)$ & $(2)$ & $(3)$ & $(4)$ \\
& HS 2004 & HS 2014 & Tertiary 2004 & Tertiary 2014 \\
\hline Log of HH income & $0.242^{* * *}$ & 0.033 & $0.184^{* * * *}$ & -0.086 \\
& $(4.07)$ & $(0.50)$ & $(3.14)$ & $(-1.31)$ \\
State employee (managerial) & $0.484^{* * *}$ & $0.918^{* * *}$ & 0.115 & $0.480^{* * * *}$ \\
& $(3.86)$ & $(3.52)$ & $(1.28)$ & $(3.78)$ \\
State employee (other) & 0.168 & -0.216 & $-0.470^{* * * *}$ & -0.185 \\
& $(1.13)$ & $(-1.21)$ & $(-3.87)$ & $(-1.24)$ \\
HH head education & $0.055^{* * *}$ & $0.078^{* * * *}$ & $0.057^{* * * *}$ & $0.051^{* * *}$ \\
& $(4.74)$ & $(6.17)$ & $(4.97)$ & $(4.19)$ \\
Urban resident & $0.263^{* * *}$ & 0.134 & $0.202^{* * *}$ & $0.316^{* * * *}$ \\
& $(2.81)$ & $(1.31)$ & $(2.47)$ & $(3.58)$ \\
Ethnic minority & $0.182^{* *}$ & $-0.375^{* * *}$ & $-0.333^{* * * *}$ & $-0.607^{* * * *}$ \\
Constant & $(1.82)$ & $(-3.51)$ & $(-2.68)$ & $(-5.04)$ \\
& $3.875^{* * * *}$ & $7.056^{* * *}$ & -0.192 & $7.422^{* * * *}$ \\
N & $(4.71)$ & $(6.78)$ & $(-0.22)$ & $(7.29)$ \\
\hline Pseudo-R2 & 2230 & 1439 & 1341 & 1330 \\
\hline
\end{tabular}

Estimates obtained using Stata probit command, robust standard errors. $z$ statistics in parentheses.

High school age range 15-18; college age range 18-22. Additional demographic controls not shown.

$* p<0.10, * * p<0.05, * * * p<0.01$ 
Table 7: Probability of being in high school or college, excluding HH income variable

(1)

\begin{tabular}{|c|c|c|c|c|}
\hline & HS 2004 & HS 2014 & Tertiary 2004 & Tertiary 2014 \\
\hline State employee (managerial) & $\begin{array}{c}0.571 * * * \\
(4.61)\end{array}$ & $\begin{array}{c}0.933 * * * \\
(3.62)\end{array}$ & $\begin{array}{l}0.171 * \\
(1.94)\end{array}$ & $\begin{array}{c}0.450 * * * \\
(3.58)\end{array}$ \\
\hline State employee (other) & $\begin{array}{l}0.209 \\
(1.41)\end{array}$ & $\begin{array}{l}-0.212 \\
(-1.19)\end{array}$ & $\begin{array}{c}-0.433 * * * \\
(-3.57)\end{array}$ & $\begin{array}{l}-0.190 \\
(-1.27)\end{array}$ \\
\hline HH head education & $\begin{array}{c}0.055 * * * \\
(4.89)\end{array}$ & $\begin{array}{c}0.079 * * * \\
(6.26)\end{array}$ & $\begin{array}{c}0.059 * * * \\
(5.11)\end{array}$ & $\begin{array}{c}0.050 * * * \\
(4.12)\end{array}$ \\
\hline Urban resident & $\begin{array}{c}0.349 * * * \\
(3.84)\end{array}$ & $\begin{array}{l}0.145 \\
(1.45)\end{array}$ & $\begin{array}{c}0.268^{* * *} \\
(3.44)\end{array}$ & $\begin{array}{c}0.291 * * * \\
(3.37)\end{array}$ \\
\hline Ethnic minority & $\begin{array}{l}0.111 \\
(1.14)\end{array}$ & $\begin{array}{c}-0.392 * * * * \\
(-3.84)\end{array}$ & $\begin{array}{c}-0.395 \text { **** } \\
(-3.22)\end{array}$ & $\begin{array}{c}-0.568 * * * \\
(-4.93)\end{array}$ \\
\hline Constant & $\begin{array}{c}6.162^{* * * *} \\
(10.46) \\
\end{array}$ & $\begin{array}{c}7.401^{* * * *} \\
(9.85) \\
\end{array}$ & $\begin{array}{c}1.412 * * \\
(2.01) \\
\end{array}$ & $\begin{array}{c}6.526 * * * * \\
(8.58) \\
\end{array}$ \\
\hline $\mathrm{N}$ & 2230 & 1439 & 1341 & 1330 \\
\hline Pseudo-R2 & 0.123 & 0.181 & 0.059 & 0.125 \\
\hline
\end{tabular}

Estimates obtained using Stata probit command, robust standard errors. $z$ statistics in parentheses.

High school age range 15-18; college age range 18-22. Additional demographic controls not shown.

$* p<0.10, * * p<0.05, * * * p<0.01$ 


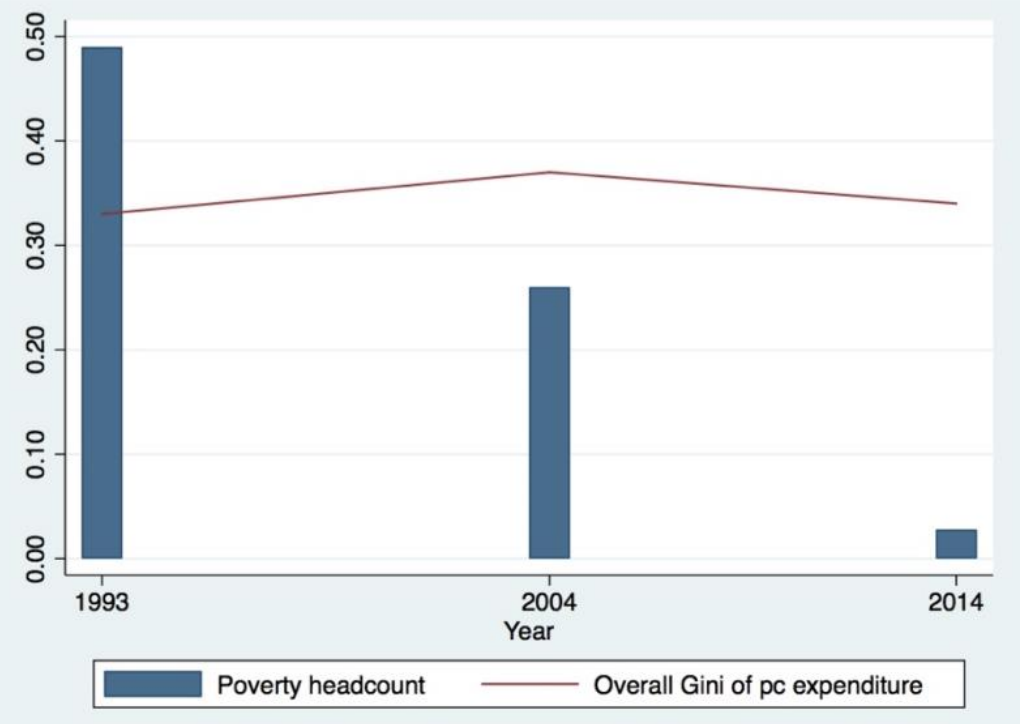

Figure 1: Changes in poverty and inequality, 1993-2014

Sources: Poverty headcount data (based on \$1.90/day poverty line) from World Bank; Gini indices from Benjamin, Brandt, and McCaig 2017. 


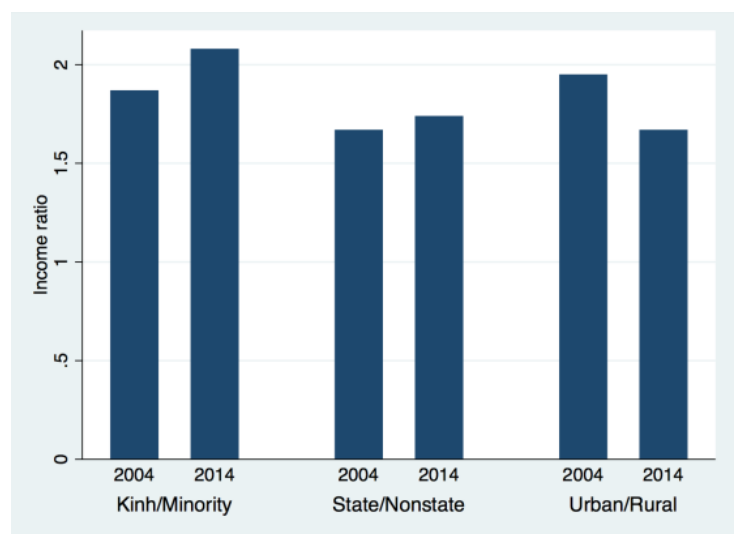

Figure 2a: Mean household income ratios

Note: Column height $=$ ratio of average per capita incomes

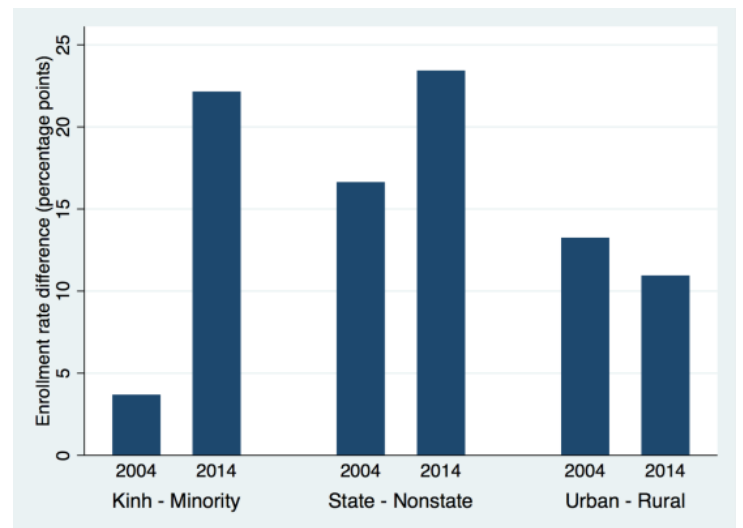

Figure 2b: Mean high school enrollment difference

Note: high school enrollment rate $=$ children aged 15-18 enrolled, as percentage of those having completed 9 th grade .

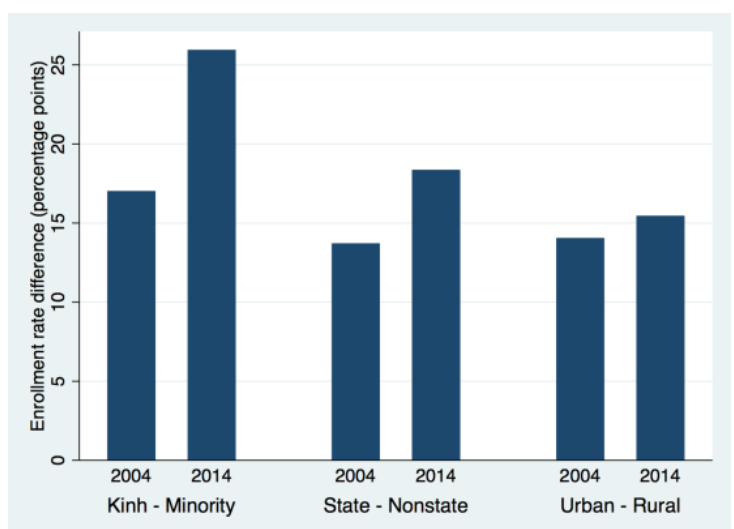

Figure 2c: Mean tertiary enrollment difference

Note: tertiary enrollment rate $=$ youths aged 18-22 enrolled, as percentage of those having completed grade 12.

Figure 2: Comparisons of income and enrollment (Source: authors' calculations using VHLSS data) 

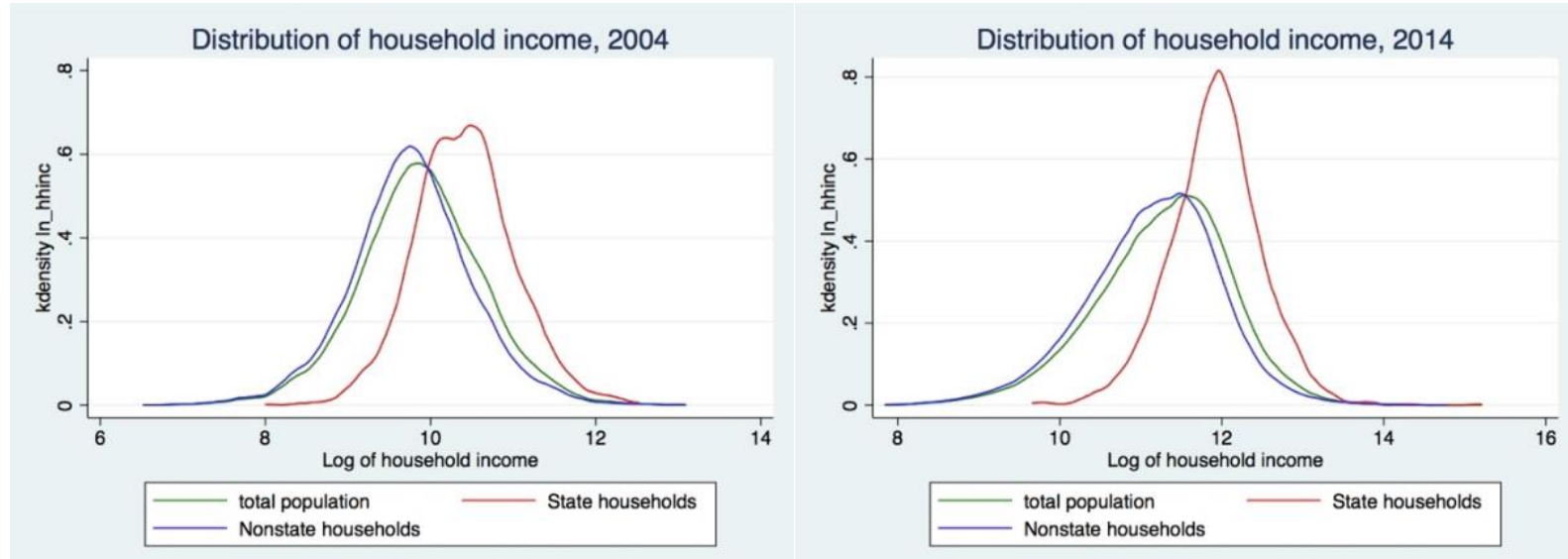

Figure 3: Distribution of household income, 2004 and 2014 (Source: VHLSS)
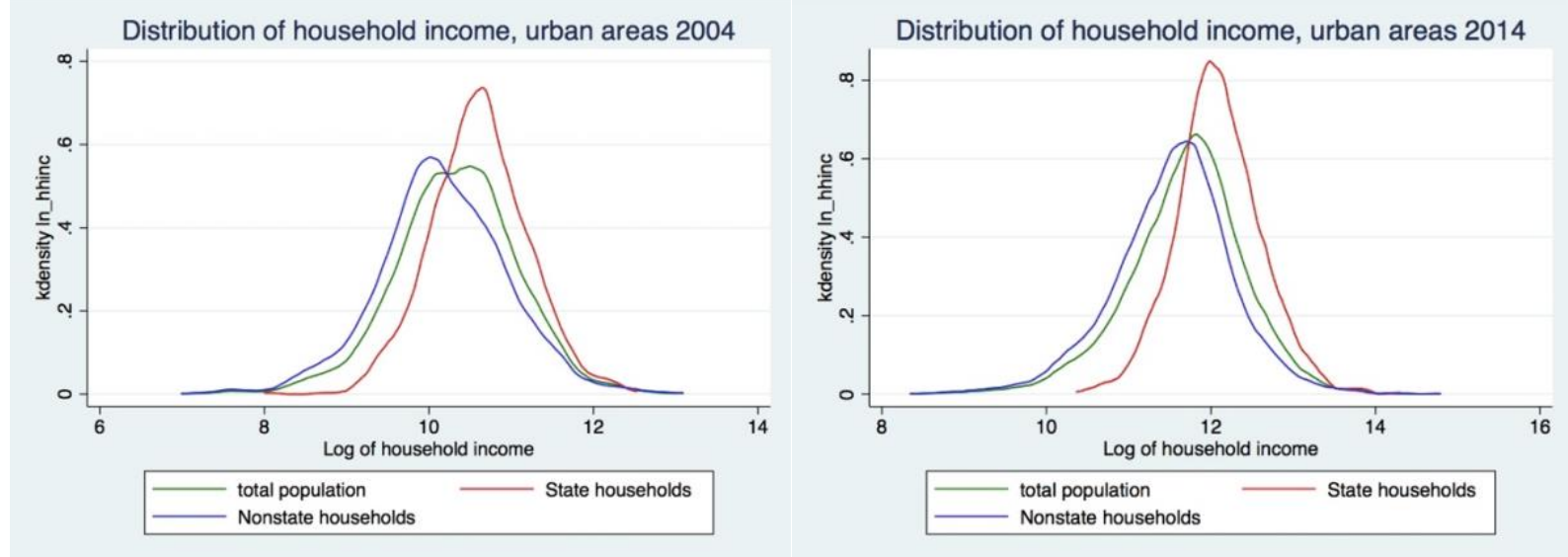

Figure 4: Distribution of urban household income, 2004 and 2014 (Source: VHLSS) 


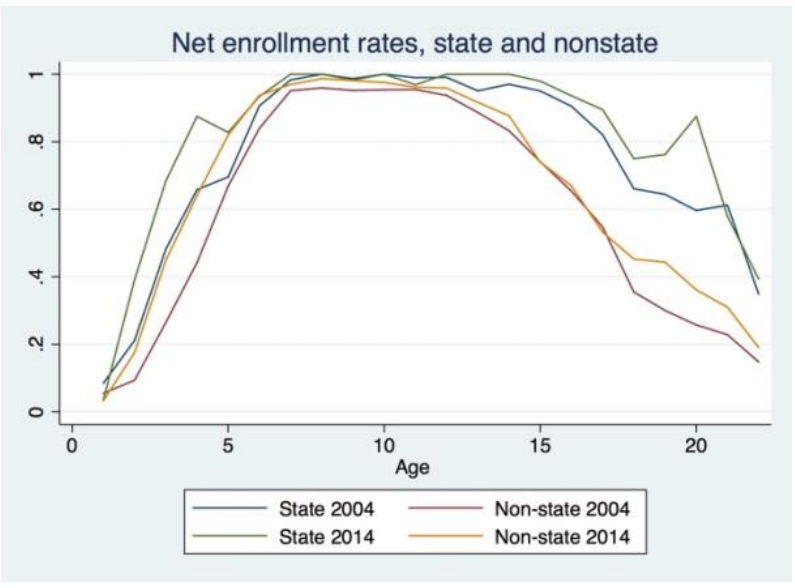

Figure 5: Net enrollment rates, children from state and non-state households (Source: VHLSS)

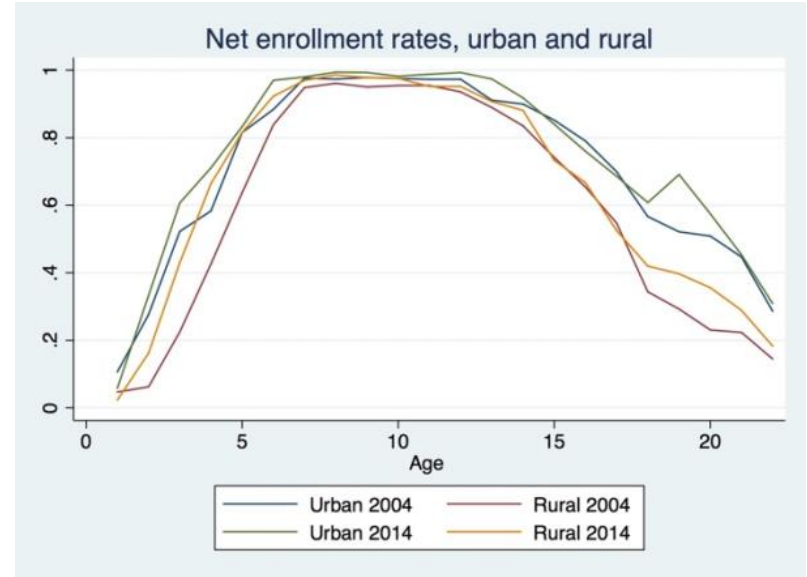

Figure 6: Net enrollment rates, children from urban and rural households (Source: VHLSS)

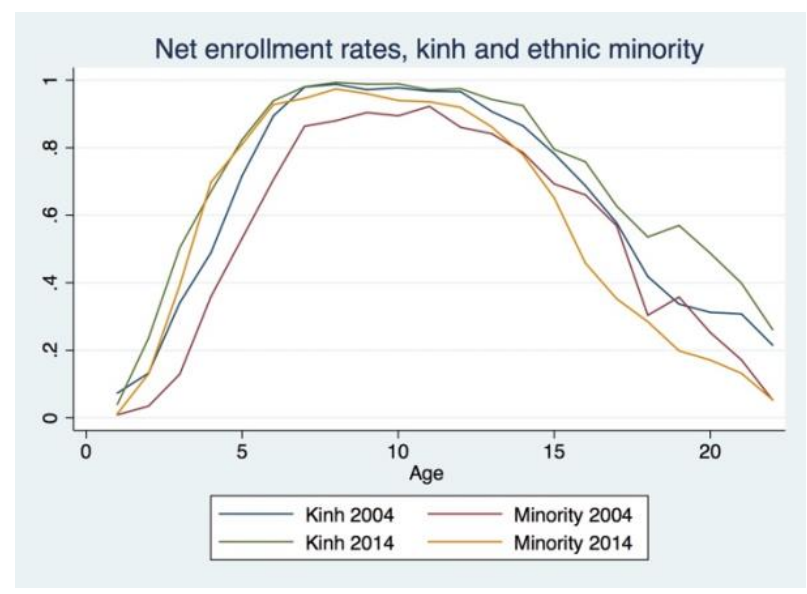

Figure 7: Net enrollment rates, children from ethnic majority (kinh) and minority households (Source: VHLSS) 